\title{
Student Engagement as the Factor of Math Mastery in University: The Relationship Between Social Factor and Learning Practices
}

\author{
Nora'asikin Abu Bakar', Ahmad Fauzi Mohd Ayub², \\ Nor Aniza Ahmad ${ }^{3}$, Sharifah Intan Sharina Syed Abdullah ${ }^{4}$ \\ ${ }^{12}$ Institute for Mathematical Research, Universiti Putra Malaysia, Malaysia \\ ${ }^{234}$ Faculty of Educational Studies, Universiti Putra Malaysia, Malaysia \\ Email: afmy@upm.edu.my
}

Article History: Received: 10 November 2020; Revised 12 January 2021 Accepted: 27 January 2021; Published online: 5 April 2021

\begin{abstract}
The main aim of math teaching at the higher level is to form students' competency to prepare them for other courses that require mathematical skills and professional task solving. The challenge today is to develop student engagement in math learning. Thus, this study examined the relationship between social factors, student learning practices, and student engagement in math learning. A survey through questionnaires was distributed to 284 bachelor's degree students at a private university in Malaysia. For data analysis, descriptive statistics and Structured Equation Modeling were applied. The results obtained revealed that there were significant relationships between: a) teaching practices and attentive listening, note-taking, working on in-class problems, b) peer influence and attentive listening, c) parental involvement and working on in-class problems, and the amount of homework completed. The results also show that seating location, attentive listening, note-taking, working on in-class problems, and homework completion have a significant relationship with student engagement in math learning.
\end{abstract}

Keywords: teaching practices, peer influence, parental involvement, attentive listening, note-taking

\section{Introduction}

Learning math is believed to be the best way to form logical thinking that help student face professional challenges today (Maron, 2016). By learning math, thinking creatively, critically, and practically in solving any issue can be developed. Given that math skills are needed in advanced learning and the occupational world, student engagement in math concourses highly important. Student engagement can ensure the mastery of knowledge and skills (Wang \& Degol, 2014). Behavior engagement, cognitive engagement, and affective engagement can increase the learning outcome's quality (Fredricks et al., 2004; Lam et al., 2016). Behavioral engagement refers to student engagement in-class activities, attendance, and the effort to understand learning (Gerber et al., 2013). Cognitive engagement encompasses gaining a better understanding, mastering the concept or skills on the materials taught (Witkowski \& Cornell, 2015). Meanwhile, the student's reactions to the lecturer, peers, course content, or class environment are affective engagement (Gunuc \& Kuzu, 2015).

Usually, learning at the university involves a big lecture hall, and students are more passive or less engaged during the teaching process (Ketonen et al., 2016). Student engagement, especially early on, is crucial during the university entrance because the low achievement in the introductory course and the pre-requirement courses like algebra can lead to course drop and students lagging (Shernoff, Ruzek, et al., 2017). Student engagement improves the learning outcome and becomes the platform to enhance the relationship between the lecturer or classmates, and it will be fun to learn (Conner, 2016; Gunuc \& Kuzu, 2015). Besides being in the class, student engagement on academic tasks outside class hours is also essential (Bembenutty \& White, 2013; Buijs \& Admiraal, 2013; Flunger et al., 2017; Mehmood, 2012). Students involved in task implementation are found to have high discipline, motivation, and self-regulation.

This study looks into student engagement in math learning based on student's learning practices. Throughout the learning process, the practice can picture student engagement level (Reschly \& Christenson, 2012; SalmelaAro et al., 2016; Shernoff, Ruzek, et al., 2017; Shernoff, Sannella, et al., 2017). Among the learning practices that can be employed to measure the level of student engagement are the seating location, note-taking, attentive listening, and working on in-class problems (Shernoff, Ruzek, et al., 2017). Classroom research shows that the learning practices can impact the quality of the learning outcome (Shernoff, Ruzek, et al., 2017). Other than that, the practice of submitting complete homework can also measure student engagement, as the amount of homework completed has a significant relationship with student engagement (Núñez, Suárez, Cerezo et al., 2015). 


\subsection{Seating Location}

The seating location can explain student engagement in class because different locations will give other engagement effects (Csikszentmihalyi, 2014; Shernoff, Ruzek, et al., 2017). The front position has a significant positive impact on student engagement (Montello, 1998; Shernoff, Ruzek, et al., 2017; Shernoff, Sanella, et al., 2017). Students who sit in front have a high flow of concentration (Holliman \& Anderson, 1986). They tend to be more engaged, and usually, their grades are better than students who would choose far at the back of the class or hall. Sitting close to the lecturer can help the students see and listen to the teaching (Holliman \& Anderson, 1986). Besides, this can also increase the interaction with the lecturer and spur the students to become more engaged in class activities. Sitting at the back, by contrast, will lower student's capability to see and listen to the lecture. The distance can also increase learning disruption and reduce the student's participation (Montello, 1988). Thus, students sitting at the back cannot focus on the teaching (Csikszentmihalyi, 1990; Shernoff, 2013; Shernoff, Sanella, et al., 2017). Jover and Ramírez (2018) study that most university students usually do not choose to sit in the first row. However, this is not a primary concern as sitting close to the lecturer does not give any effective student performance (Jover \& Ramírez, 2018). Besides that, the students' seating location can also influence the teachers' perception of the students (Fernandes et al., 2011). The students who choose to sit far back are assumed to lack the interest to get engaged. The study by Marx et al. (2000) shows that the seating location is influenced by students' perception of the teacher, the teacher's relationship, and the relationship with friends. This study proposes that this relationship is examined to see the effect of seating location on the students.

\subsection{Note-Taking and Attentive Listening}

Note is a summary, and an essential gist from the subjects learned so that a good note would indicate one's understanding of the lesson taught (Kiewra, 1989; Kiewra et al., 1991). Note-taking helps students remember the things they learn (Carter \& Van Matre, 1975; Fisher and Harris, 1974; Kiewra, 1989; Kiewra et al., 1991). However, note-taking and the perfect one depend on the practice of listening actively (Kiewra, 1989; Kiewra et al., 1991). Note-taking is a depiction of student engagement in lecturer teaching (Witkowski \& Cornell, 2015). According to Fisher and Harris (1974), note-taking has a positive relationship with student engagement. Students who pay attention to the lecturer's delivery and take notes will usually demonstrate excellent performance (Carter \& Van Matre, 1975). That said, student performance depends on the note-taking technique and the quality of the note taken (Fisher \& Harris, 1974), and the outcome of student engagement when revising the notes (Carter \& Van Matre, 1975). Note-taking and listening attentively are intertwined as note-taking necessitates concentration on the lecture delivered so that important points or the gist can be written down (Shernoff, Ruzek, et al., 2017). Although both these practices have an interactive relationship with behavioral engagement, listening actively is scarcely discussed in studies on engagement (Shernoff, Ruzek, et al., 2017). Today, taking pictures is more prevalent among university students than jot down notes (Mfaume et al., 2018). This trend is caused by fast lecture delivery, reduced skills and speed in taking notes, disturbance of concentration, easy access to notes, peer influence, and technological advancement (Mfaume et al., 2018). Moreover, because very few studies have examined whether attentive listening and note-taking are still mutually dependent, we strive to understand the effect of attentive listening and note-taking on student engagement.

\subsection{Working on In-Class Problems}

The practice of solving problems during class is also vital as the student's behavior, and effort in solving the challenges can explain the level of student engagement (Shernoff, Ruzek, et al., 2017). The application of newly learned skills to resolve learning issues shows student engagement during teaching (Csikszentmihalyi, 1990; Shernoff, 2013; Shernoff, Ruzek, et al., 2017). Problem-solving involving behaviors like asking questions or getting lecturers' or peers' assistance also shows self-regulation and learning motivation that is important in developing student engagement (Pintrich \& De Groot, 1990). That said, the problem posed should be appropriate with the skills taught to be resolved with reasonable efforts (Shernoff, Ruzek, et al., 2017). This is because problems that are too difficult and outdo students' capability can trigger worry and even panic. By contrast, problems that are also easy and do not challenge students' ability cause them not to feel excited to solve them (Shernoff, Ruzek, et al., 2017). Based on the study reviewed earlier, does working on in-class problems affect student engagement in math learning?.

\subsection{The Amount of Homework Completed}

Homework is meant to consolidate knowledge, increase students' mastery and skills (Rosário et al., 2018). Simultaneously, homework enables teachers to detect students' level of understanding about the materials taught (Rosário et al., 2018). In learning math in university, homework is vital as mathematical, conceptual exercise, and consolidation (Holland-Minkley \& Lombardi, 2016). In several studies (e.g., Flunger et al., 2017; Núñez, Suárez, Cerezo et al., 2015; Shaari et al., 2014; Valle et al., 2016) show that the implementation of academic tasks has a positive relationship with student engagement. The study by Flunger et al. (2017) finds that intrinsic motivation, discipline, and study behavior are inextricably linked with student engagement on the task implementation. 
However, past studies (e.g., Núñez, Suárez, Cerezo et al., 2015) establish that the amount of homework completed and the time management quality of the homework decrease when the students' learning phase is increasing. Student engagement management through the amount of homework is also emphasized in Valle et al. (2016). Thus, we seek to identify how far the university students can carry out their math tasks and any relationship between homework completion and student engagement in math learning at the university level.

\subsection{Social Factors}

In math learning, student engagement is associated with: teacher factor (Attard, 2012; Engels et al., 2016; Lee \& Reeve, 2012; Pöysä et al., 2019; Skilling, 2014; Vollet et al., 2017), lecturer factor (Heng 2014a; Kahu 2013; Leach, 2014; Mehdinezhad, 2011; Muda et al., 2012), peer factor (Engels et al., 2016; Nguyen et al., 2016; Sathappan, 2017; Uzezi \& Deya, 2017; Witkowski \& Cornell, 2015), and parents factor (Al-Alwan, 2014; Arshad \& Shahzadi, 2016; Lowe \& Dotterer, 2017). Previous studies (e.g., Fredricks et al., 2004; Marx et al., 2000; Shaari et al., 2014; Shernoff, Ruzek, et al., 2017; Vansteenkiste et al., 2012) show that the teaching practice influences the perception and student engagement on the course they take. Teaching practice refers to the lecturer's ways to create a positive environment in the class, build relationships with the students, and increase students' understanding (Skilling, 2014). Lecturer's factors like task quality, evaluation method, and feedback urgency affect students' engagement (Holland-Minkley \& Lombardi, 2016). They find that student engagement increases when lecturers submit the work after it has been revised.

Other researchers (e.g., Furrer et al., 2014; Kessels et al., 2014; Lynch et al., 2013; Molloy et al., 2011; Uzezi \& Deya, 2017; Vollet et al., 2017) found that peers can also influence the learning practices in class. Peers refer to friends from the same age group that forms moral, personal, and behavioral developments (Lynch et al., 2013). Other than that, students' needs for their parents' involvement do not end, although they have entered the university and into adulthood (Arshad \& Shahzadi, 2016). Parents' involvement refers to their support in emotional, informational, and physical aspects of their children's learning (Lowe \& Dotterer, 2018). Parents are the most crucial social agent in the students' lives (Wang \& Eccles, 2012). Thus, parents' involvement influences the formation of students' engagement (Deka, 2016; Harper et al., 2012; Svoboda et al., 2016; Wang \& Eccles, 2012). To conclude, social support from lecturers, peers and parents can fulfill the needs for relationships, competency, and autonomy required to develop student engagement in learning (Deci \& Ryan, 1985, 2000).

Student engagement is a dynamic process which means that it is constantly changing. Studies on the learning practices can understand student engagement level (Salmela-Aro et al., 2016; Shernoff et al., 2013; Shernoff, Ruzek, et al., 2017). This knowledge improves the quality of student engagement and their learning experience. (Shernoff, Ruzek, et al., 2017). This study will give a specific input about the learning practices to guide students who are weak in math until they achieve vital mastery. Understanding the social factor can help the development of student engagement in math learning. The exploration into the learning aspect and the social element can also contribute to implementing learning math strategy to achieve a quality outcome. Thus, it can lead to excellence in math. This study will add value to a limited research topic related to learning practices, social factors, and student engagement.

\section{Research Question}

In this study, student engagement refers to the three-dimensional construct of engagement: behavior, cognitive and affective specified in math learning. The structure model is analyzed using SEM to identify the relationship between learning practices and student engagement. At the same time, we also seek to understand the extent of the relationship between the teaching practices, peer influence, and parental involvement in all the five ways put forth. Based on the structure model on the data obtained, the following questions have been formulated:

- Do the seating location, attentive listening, note-taking, working on in-class problems, and homework completed affect student engagement in math learning?

- Is there any relationship between teaching practices, peer influence, and parental involvement with seating location, attentive listening, note-taking, working on in-class problems, and the amount of homework completed? 
Figure 1 shows the hypothesis path model.

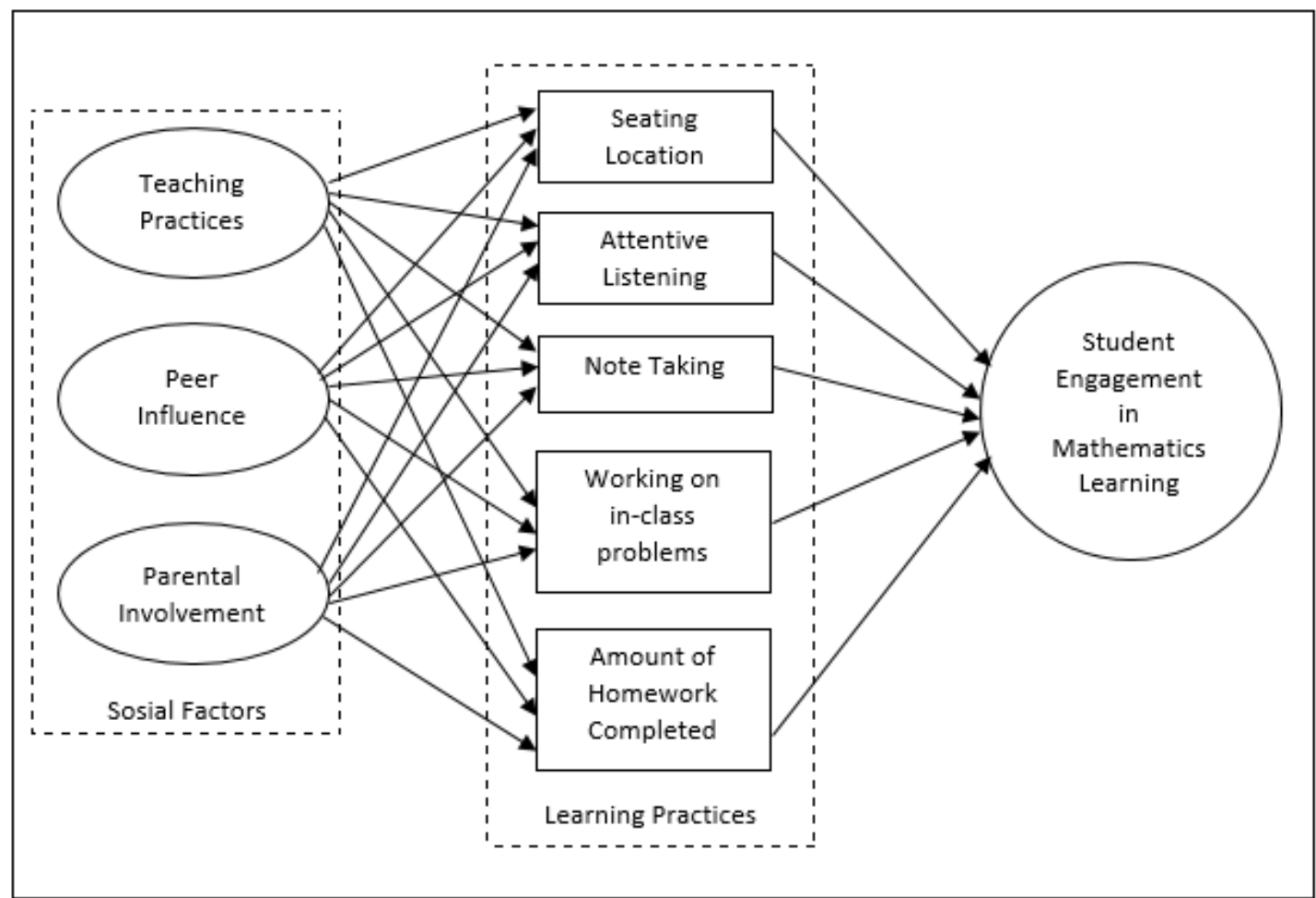

Figure 1. Hypothesis path model to explain the relationship between social factors, learning practices, and student engagement in math learning

\section{Methodology}

This study leans on the Flow Theory, a fundamental concept structure that is dynamic and useful in describing students' engagement levels. Several studies have used flow Theory (e.g., Gunuc, 2014; Gunuc \& Kuzu, 2015; Reeve \& Tseng (2011), Shernoff et al., 2013; Shernoff et al., 2016; Shernoff, Ruzek, et al., 2017) to explain the association between the flow experience, the level of student engagement and the achievement of a learning outcome. In this theory, Csikszentmihalyi (1990) explained the flow, which is the engagement on the optimal level when doing an activity. The flow is formed from the motivation or aim that has been set. When there is a flow, individuals will pay great attention to the activity done with a disregard to the time, tiredness, or other selfneeds. Student engagement is the existence of flow, seeing this interest and fun to keep learning (Shernoff et al., 2013). For instance, the current flow of accomplishing the tasks favored shows the formation of affective and cognitive engagement on the given tasks (Shernoff \& Csikszentmihalyi, 2009). Other than that, the Flow Theory also can relate to high engagement levels, teacher factors, and quality of learning outcomes (Csikszentmihalyi, 2014). Despite the complex and challenging learning tasks, the flow increases if students are clear with the requirement and expectation for the activity or task assigned (Gunuc, 2014; Shernoff et al., 2016). Thus, the balance between learning challenges and teaching practices is vital to increase students' quality of the flow experience. In math, learning, problem-solving, and task completion are essential components. Finding the answers for mathematical problems requires axiom, algorithms, and exact steps that are sometimes confusing and intricate. Although self-regulation and the existing mathematical knowledge are crucial to mathematical learning, if it is assumed that students can feel excited about learning math, the flow can be increased. This study adopts the learning practices measurement from Shernoff, Ruzek, et al. (2017) to measure student flow in math learning. Additionally, the impact of the social factors on the learning practices was also examined. The measurement of this relationship is important so that an appropriate learning practice can be practiced among students.

\subsection{Sample}

The sample selection is carried out using the stratified random sampling technique based on the math course offered in June 2019. Data were gathered from a sample of 284 bachelor's degree students aged between 19 and 24 years old. From the sample, 218 (76.8\%) males and $66(23.2 \%)$ are female. In terms of the study found, the majority of the students $(159,56 \%)$ funded by parents, while $92(32.4 \%)$ students use loan facility, followed by 23 students $(8.1 \%)$ paying for their fees and only $10(3.5 \%)$ students received a scholarship. 


\subsection{Procedure}

Three hundred students who registered for the math course in the semester of June 2019 and were interested in participating in the study were asked to sign and return a consent form. Data were collected through a selfadministered questionnaire which took approximately 20 minutes to complete. This data collection took place in designated math classrooms in one of the private universities in Malaysia with the lecturer in attendance.

\subsection{Measures}

\subsubsection{Student engagement in math learning}

The level of student engagement was assessed based on three dimensions, i.e., behavioral engagement (e.g., "I don't participate in math class," "I spend enough time doing math assignments"), cognitive engagement (e.g., "Whenever learning math becomes tough, I only study the easy part," "I do the best in my math assignments"), and affective engagement (e.g., "I feel that the math class is boring," "I get worried when I learn new things about math"). Items of this construct were adapted from the studies by Wang et al. (2016) and Flunger et al. (2015). The instrument is rated on a 5-point Likert scale with responses ranging from "1" strongly disagree to "5" strongly agree. The reliability of the scale was very good $(\alpha=0.90)$.

\subsubsection{Social Factors}

Teaching practices were measured using the instrument developed by Oliver et al. (2008) and were adapted and modified. For this study, only a subscale of teaching practices (i.e., readiness and concern) was used. Examples of items are: "My math lecturer was reasonably accessible for help" and "My math lecturer makes sure I understand before he/she goes on." Meanwhile, the measurement of peer influence is obtained from responses to the item adapted from the study by Uzezi and Deya (2017). Examples of items are: "My math understanding is better when I study with my friends," "I learn more in math while doing exercises with my friends than when I do it alone." Students also responded to several items regarding their perception of parents' involvement. These items were adapted from the work of Liu et al. (2010) (e.g., "My parents encourage me to keep on trying when I get stuck in math assignments," "My parents ask me to get help whenever I have a math problem is hard to be solved"). Students responded to all the items based on a 5-point Likert scale ranging from "1" strongly disagree to "5" strongly agree. The reliability of all scales were good, where teaching practices $(\alpha=0.88)$, peer influence $(\alpha=$ $0.82)$ and parental involvement $(\alpha=0.85)$.

\subsubsection{Learning Practices.}

Learning practices were measured based on five items, i.e., seating location, attentive listening, note-taking, working on in-class problems, and amount of math assignments completed. The first four were adapted and modified from the instrument developed by Shernoff, Ruzek, et al. (2017). However, the fifth item was adapted from the study conducted by Fernández-Alonso et al. (2015). The seating location was obtained from the answer to the question, "Where were you seated during the survey?". Choices given to students were (5) First row, (4) Second to third row, (3) Middle section, (2) Third to second row, and (1) Last row. Students were also requested to state their level of agreement with the following: "In math class, I listen to the lecturer attentively," "In math class, I jot down notes," "I worked on math problems given by the lecturer during class." The responses for the three questions were classified as (5) Strongly agree, (4) Agree, (3) Sometimes agree, (2) Disagree, and (1) Strongly disagree. Lastly, students were asked to evaluate the amount of homework completed which was "The amount of math assignments I usually complete is...". Choices available for the students were (5) All, (4) Almost all, (3) Half, (2) A little, and (1) None.

\section{Data Analysis}

This study used AMOS 23 to analyze data. Confirmatory factor analysis was conducted to assess the degree to which the structure of student engagement, teaching practices, peer influence, and parental involvement fits the data. Structural Equation Modeling (SEM) was used to answer the research questions. Firstly, data was examined, and a total of $1.7 \%$ of the data was discarded due to incomplete responses (over $10 \%$ missing). Other responses with missing values not exceeding $10 \%$ were replaced with the median value (Allison, 2003; Zhang, 2016). Next, based on the kurtosis and skewness obtained (Table 1), the maximum likelihood method was performed to determine the hypothesized model's fit. The decision on model fit was made based on Hair et al. (2010). The fit indices representing the three fit model categories (absolute fit, incremental fit, and parsimonious fit) were reported. Relative Chi-square (CMIN/DF < 5.0), Comparative Fit Index (CFI > .90) and Root Mean Square of Error Approximation (RMSEA $<.80$ ) with factor loadings $>.50$ indicated best fit to the data overall. Figure 2 shows the standard path coefficients for the hypothesized model with an adequate fit to the empirical data (Chisquare $=914.26, \mathrm{df}=536$, Relative Chi-square $(\mathrm{CMIN} / \mathrm{DF})=1.71<5.0, \mathrm{CFI}=.92>.90, \mathrm{TLI}=.91>.90, \mathrm{RMSEA}$ 
$=.05<.08$ and factor loading between .54 and $.90>.50)$. This model contributes about $86 \%$ of student engagement variability in math learning $\left(\mathrm{R}^{2}=0.86\right)$.

Table 1. The Variable Mean, Standard Deviation, Skewness, Kurtosis, and Correlation

\begin{tabular}{|c|c|c|c|c|c|c|c|c|c|}
\hline Variable $(n=284)$ & $(1)$ & $(2)$ & (3) & $(4)$ & $(5)$ & $(6)$ & $(7)$ & $(8)$ & $(9)$ \\
\hline (1) Student engagement & 1 & & & & & & & & \\
\hline (2) Seating location & $-.21 *$ & 1 & & & & & & & \\
\hline (3) Attentive listening & $.14^{*}$ & .01 & 1 & & & & & & \\
\hline (4) Note-taking & $.21 * *$ & .07 & $.42 * *$ & 1 & & & & & \\
\hline $\begin{array}{l}\text { (5) Working on } \\
\text { in-class problems }\end{array}$ & $.13 *$ & .01 & $.30 * *$ & $.32 * *$ & 1 & & & & \\
\hline $\begin{array}{l}\text { (6) Amount of homework } \\
\text { completed }\end{array}$ & $.20 * *$ & .10 & $.16^{* *}$ & .11 & $.18 * *$ & 1 & & & \\
\hline (7) Teaching practices & $.21 * *$ & .05 & $.42 * *$ & $.40 * *$ & $.33 * *$ & .08 & 1 & & \\
\hline (8) Peer influence & $.15^{*}$ & .00 & $-.16^{*}$ & -.02 & .04 & -.02 & $.15^{*}$ & 1 & \\
\hline (9) Parental involvement & -.05 & .08 & .08 & .07 & $.22 * *$ & $.16^{* *}$ & $.19 * *$ & .15 & 1 \\
\hline Mean & 2.81 & 3.49 & 4.23 & 4.13 & 4.01 & 3.97 & 4.05 & 3.73 & 4.00 \\
\hline $\mathrm{SD}$ & .60 & 1.02 & .76 & .94 & .93 & 1.03 & .73 & .86 & .84 \\
\hline Skewness & -.05 & -.44 & -.55 & -.99 & -.77 & -.90 & -.80 & -.43 & -.80 \\
\hline Kurtosis & -.60 & .14 & -.59 & .68 & .29 & .24 & .93 & .50 & .31 \\
\hline
\end{tabular}

\section{Findings}

\subsection{Descriptive Analysis}

The correlation between variables in the hypothesized model is shown in Table 1. Teaching practices have a significant positive relationship with attentive listening, note-taking, and working on in-class problems. In comparison, peer influence shows a negative relationship with attentive listening. There was a positive relationship between parental involvement and working on in-class issues and homework completion. All these learning practice variables are shown to have an impact on student engagement. The descriptive analysis reported the following findings, which are (a) a medium level of engagement in math learning $(\mathrm{M}=2.81, \mathrm{SD}=.60)$; (b) preferred to sit in the middle section during math class $(40.8 \%)$, reported an attentive listening (82.4\%), did notetaking $(76.3 \%)$, did worked on in-class problems $(73.2 \%)$, and usually submitting incomplete math assignments $(63.7 \%)$

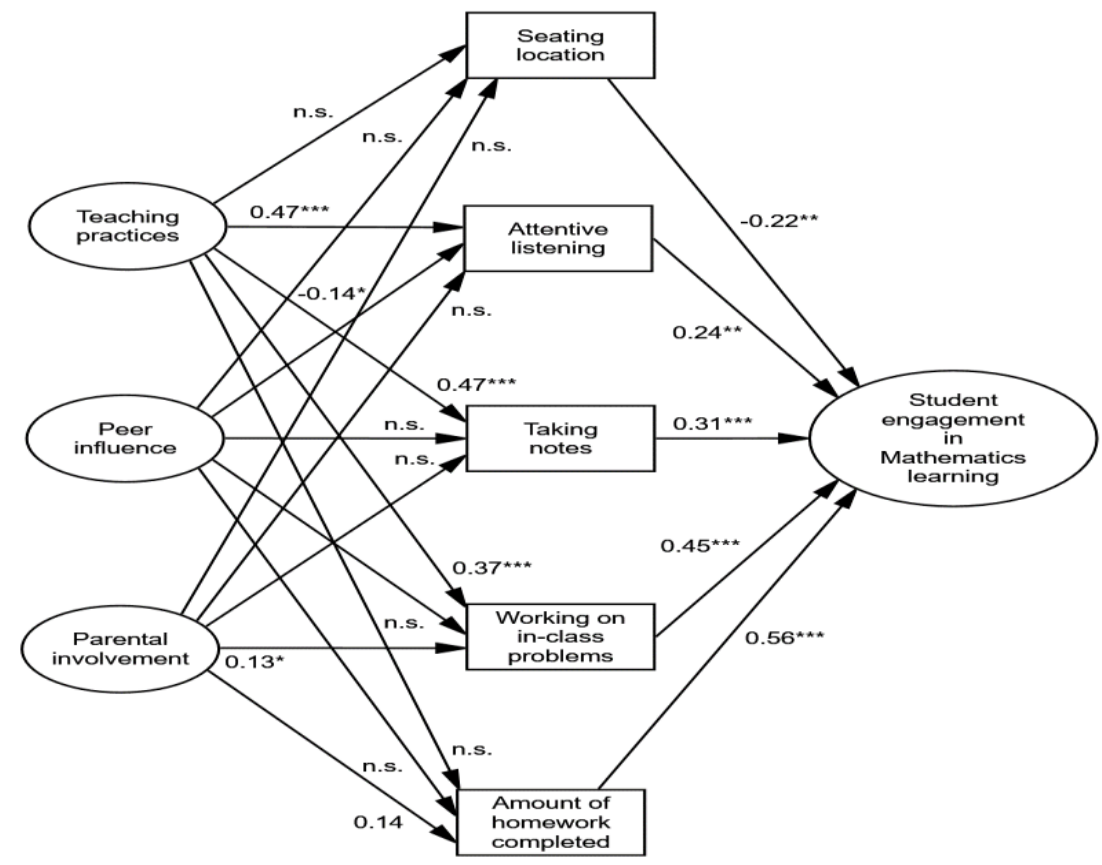

Figure 2. The results of the fit of the hypothesized model (standardized outcomes) (Note: n.s. $=$ insignificant, $* P<0.05, * * p<0.01, * * * p<0.001$ ) 


\subsection{Testing the Paths between Learning Practices and Student Engagement in Math Learning}

Referring to Table 2, a significant positive relationship exists between attentive listening $(\beta=0.244, p<0.01)$, note-taking $(\beta=0.31, p=0.00)$, working on in-class problems $(\beta=0.48, p=0.00)$, and the amount of homework completed $(\beta=0.51, p=0.00)$ with student engagement. While the relationship between seating location and student engagement is a significantly negative relationship $(\beta=0.22, p<0.01)$. The findings indicated that all five learning practices studied gives an impact on student engagement in learning math.

Table 2. Results for the Paths between Learning Practices and Student Engagement

\begin{tabular}{llllll}
\hline & $\mathbf{B}^{\mathbf{a}}$ & $\mathbf{B}^{\mathbf{b}}$ & $\mathbf{S E}$ & $\mathbf{C R}$ & $\mathbf{P}$ \\
\hline Seating location $\rightarrow$ Student engagement & 0.07 & 0.22 & 0.03 & 2.61 & 0.01 \\
Attentive listening $\rightarrow$ Student engagement & 0.10 & 0.24 & 0.04 & 2.60 & 0.01 \\
Note-taking $\rightarrow$ Student engagement & 0.10 & 0.31 & 0.03 & 3.18 & 0.00 \\
Working on in-class problems $\rightarrow$ Student engagement & 0.15 & 0.45 & 0.03 & 4.40 & 0.00 \\
Completed Amount of Assignment $\rightarrow$ Student engagement & 0.15 & 0.51 & 0.03 & 4.80 & 0.00 \\
\hline$a$ Non-standardized regression coefficients, ${ }^{b}$ Standardized regression coefficients & & &
\end{tabular}

${ }^{a}$ Non-standardized regression coefficients; ${ }^{b}$ Standardized regression coefficients

\subsection{Testing the Paths between Social Factors and Learning Practices}

The analysis results as tabulated in Table 3 does not indicate a significant relationship between seating location with teaching practices $(\beta=0.04, p>0.05)$, peer influence $(\beta=-0.01, p>0.05)$ and parental involvement $(\beta=$ $0.07, \mathrm{p}>0.05)$. This finding indicates that social factors do not influence students' seating locations during class. Attentive listening is shown to have a significant positive relationship with teaching practices $(\beta=0.47, p=0.00)$, a significant negative relationship with peer influence $(\beta=-0.14, p<0.05)$, and no relationship with parental involvement. On the other hand, note-taking shows a significant positive relationship with only teaching practice $(\beta=0.47, p=0.00)$, and no other relationships with other social factors. Working on in-class problems showed a significant positive relationship with teaching practices $(\beta=0.37, \mathrm{p}=0.00)$ and parental involvement $(\beta=0.13$, $\mathrm{p}<0.05$ ) but no relationship with peer influence. Finally, the amount of homework completed showed a significant positive relationship with parental involvement $(\beta=0.14, \mathrm{p}<0.05)$, but no indications of relationships with other social factors.

Table 3. Relationships between Social Factors and Learning Practices

\begin{tabular}{llllll}
\hline & $\mathbf{B}^{\mathbf{a}}$ & \multicolumn{1}{l}{$\mathbf{B}^{\mathbf{b}}$} & \multicolumn{1}{l}{ SE } & \multicolumn{1}{l}{ CR } & P \\
\hline Lecturer's Teaching Practices $\rightarrow$ Attentive listening & 0.53 & 0.47 & 0.07 & 7.20 & 0.00 \\
Lecturer's Teaching Practices $\rightarrow$ Note-taking & 0.66 & 0.47 & 0.09 & 7.16 & 0.00 \\
Lecturer's Teaching Practices $\rightarrow$ Working on in-class problems & 0.51 & 0.37 & 0.09 & 5.74 & 0.00 \\
Peer Influence $\rightarrow$ Attentive listening & -0.15 & -0.14 & 0.07 & -2.17 & 0.03 \\
Parental involvement $\rightarrow$ Working on in-class problems & 0.17 & 0.13 & 0.08 & 2.21 & 0.03 \\
Parental involvement $\rightarrow$ Amount of Homework Completed & 0.19 & 0.14 & 0.09 & 2.15 & 0.03 \\
\hline
\end{tabular}

${ }^{a}$ Nonstandardized regression coefficients; ${ }^{b}$ Standardized regression coefficients

\section{Discussion}

\subsection{Relationship between Learning Practices and Student Engagement in Math Learning}

This study provides an insight into learning practices that can impact student engagement in math learning. These findings can also add to the understanding of students' perceptions towards social factors and the matters that should be emphasized to increase student engagement. This study aims to examine the relationship between learning practices and student engagement in math learning. Findings indicate that the level of student engagement in learning math is at a medium level. Following the results obtained, most students' seating location is found to be in the middle of the classroom. They jot down notes, attentively listened, and worked on in-class problems; however majority of the students handed in incomplete homework.

Other researchers (e.g., Jover \& Ramírez, 2018) have found that university students would generally choose to shy away from sitting in the first row. This seating location significantly impacts the students' attention flow, seeing that sitting near the lecturer would reduce learning interruption (Shernoff, Ruzek, et al., 2017). Seating locations also proved to influence students' behavior and discussion with the lecturer. Student engagement during class is critical to ensure students' mastery (Wang \& Degol, 2014) and to increase the quality of learning outcomes (Fredricks et al., 2004; Lam et al., 2016). Therefore, sitting near the lecturer is the best position as the distance is closer, reducing the risk of interrupted attention towards learning (Montello, 1988). A suitable seating location can provide comfort, visual clarity, and better students' movement during face-to-face learning (Meeks et al., 2013). 
In this study, attentive listening and note-taking have a significant positive relationship with student engagement suggest that positive dimensions of learning practices reflect student engagement. Note-taking that requires a flow towards the lesson helps to increase the understanding of the matter being taught (Csikszentmihalyi, 2014; Pintrich \& De Groot, 1990)-increased knowledge of lessons increases learning motivation (Csikszentmihalyi, 2014; Pintrich \& De Groot, 1990) which will give an impact on student engagement. Note-taking and attentive listening may also increase the student's power of thought (Carter \& Van Matre, 1975; Fisher dan Harris, 1974; Kiewra, 1989; Kiewra et al., 1991), therefore providing an impact among students. In this case, measuring the attentive listening and note-taking offers an insight into student behavioral engagement (Shernoff, Ruzek, et al., 2017). Through this study, we can ascertain that the method of note-taking, whether through writing or taking pictures, has a significant positive impact on engagement in math learning. This finding verifies the importance of note-taking techniques and the degree of perfection of the recorded notes when mastering a lesson (Kiewra, 1989; Kiewra et al., 1991). Therefore, the trend of note-taking through taking photos will help students gain more perfect notes and may be able to bring about change in student engagement.

Current findings also suggest that working on in-class problems shows an increased impact on student engagement. The more learning challenges can be solved, the higher student engagement (Shernoff, Ruzek, et al., 2017). This occurrence demonstrates that mastering and applying the skills learned will increase students' motivation, thus paving the way to growing their engagement towards learning (Csikszentmihalyi, 2014; Pintrich $\&$ De Groot, 1990). Fitting with the nature of learning math requires plenty of practice in problem-solving. This finding suggests giving math problems during class will increase student engagement and their understanding of new lessons. Simultaneously, the given situation's difficulty level should be planned, seeing that too easy or too difficult issues may inhibit students' engagement (Shernoff, Ruzek, et al., 2017).

Next, the relationship between the amount of homework completed with student engagement found is in line with the findings by Flunger et al. (2017), which showed that the amount of completed homework indicated the level of student engagement. The low percentage of students submitting incomplete assignments indicates a moderate level of engagement in math learning. Results revealed that most students in this study did not answer all the questions given in the assignments. This finding confirms that the amount of homework completed by students at a higher education decreases in line with the decrease in their time management quality (Núñez, Suárez, Cerezo et al., 2015; Fan et al., 2017). Based on student feedback, they often submit incomplete assignments as they do not understand what is being taught during class, and some of them assume that problems given are complex (Razali et al., 2015). Therefore, the perception that math is complicated is abstract and requires a higher level of thinking to be given attention to develop engagement towards homework implementation. Concerning that, measuring the amount of completed homework will provide knowledge on student engagement and clarify the level of competence for self-regulation and setting student learning goals (Núñez, Suárez, Cerezo et al., 2015; Valle et al., 2016).

As a whole, choosing seating location, attentive listening, note-taking, and working on in-class problems explained the moderate level of engagement among private university students towards learning math. Therefore, this study suggests that the efforts to emphasize cultivating acceptable learning practices should be carried out to increase student engagement when learning math.

\subsection{Relationship between Social Factors and Learning Practices}

In this study, teaching practices influence attentive listening, note-taking, and working on in-class problems, confirming the need for relatedness (student-lecturer) and autonomy (working on in-class problems) to develop student engagement as stated in the Self Determination Theory by Deci and Ryan (1985, 2000). Descriptive analysis results reveal that a fair and approachable attitude builds a positive student perception towards the lecturer. This matter shows that students like to build good relationships between lecturer and student, thus encouraging student engagement towards learning (Durksen et al., 2017). The findings also show that readiness in helping learning and showing concern towards their learning progress promotes positive learning practices during class. Students hope lecturers will ensure that the materials taught will be understood before moving on to the following lessons. The mastery of a delivered lesson can build self-confidence, create a feeling of appreciation towards the value of knowledge, and retain student engagement (Durksen et al., 2017).

Meanwhile, for seating location and the amount of homework completed, findings indicate that teaching practices do not significantly impact learning practices. Therefore, a student's seating location choice does not depend on the lecturer factor, as homework is completed. Inversely, both these items may be influenced by the students' factors. This study exhibits that teaching practices do not affect the amount of math homework completed by the student and incomplete or not submitted assignments. Based on the findings, it is revealed that the understanding of teaching practices can explain the level of student engagement in terms of attitude, affective and cognitive (Shernoff, Ruzek, et al., 2017). Current findings also revealed that teaching practices in the form of 
preparedness and concern might avoid student inhibition which may indirectly empower students' mastery in math (Skilling, 2014).

Findings from this study show that peer influence has a significant negative relationship with attentive listening, which means that peers affect the focus towards the lecturer's teachings. Typically, peer influence occurs as students regularly share similar activities on campus. Therefore a close bond among students may impact their learning (Molloy et al., 2011). Consequently, every unique peer relationship plays a role in influencing student adaptability towards learning styles in university and forming learning practices during class (Molloy et al., 2011). These findings are concurrent with Lynch et al. (2013), who showed that peer influence is more substantial over friends who are less involved with lecturers. Peer influence is more vital in students at a higher education level (Molloy et al., 2011). In other words, peers can increase or even decrease student engagement (Vollet et al., 2017). Distraction towards a lecturer's teaching happens typically when a student is more attracted to listen, verbally reply, or reply to Whatsapp messages from their friends (Sathappan \& Sathappan, 2017). This study reveals that students consider their friends the most important source to obtain information and aid learning. This dependence on their peers to understand difficult subjects is the cause of this notion (Furrer et al., 2014). With that, the implementation of group activities will help develop student engagement in math learning, group collaboration, and exchanging views to attract students to be more involved in education (Min \& Chau, 2012; Stebleton et al., 2014). Other than that, positive peer relationships may also help students handle university challenges and drive acceptable learning practices (Ribera et al., 2017). Next, there is no correlation between peer influence with seating location, note-taking, in-class math problem solving, and homework completion. Current findings also suggest that all four learning practices are not influenced by peers but depend on individual factors such as awareness towards the importance of learning math. These findings fit those by Gunuc (2014), Heng (2014b), Leach (2016), and Valle et al. (2016), who all found that learning practices are the result of self-regulation and appreciation of the value of learning. In terms of note-taking, having a smartphone to capture pictures or record the lecturer's presentation may well be among why the dependence on peers for notes is no longer significant (Mfaume et al., 2018).

Results showed a significant positive relationship between parental involvement with working on in-class problems and the amount of homework completed. This indicates that parental involvement brings a positive impact on student's attitudes and behaviors in their learning. In line with past studies (e.g., Jelas et al., 2016; Mehdinezhad, 2011), current finding shows that parental involvement is crucial in every education level. Parental support can form self-regulation and learning strategies in the student. Parental involvement such as behavioral involvement, interaction, and academic support increases students' motivation, encouraging them to get involved in academic tasks (Grolnick \& Slowiaczek, 1994). Usually, parental involvement seems to decrease as the child approaches adulthood as they perceive their adult children to be more capable in handling their learning (Abd Razak \& Noraini, 2011). However, current findings show that parental support for the students always to be positive towards math assignments shows a significant impact. Students also believe that parental involvement increases their confidence to overcome challenges in learning math and encourages them to solve math problems as well as possible. That is, parental involvement from a social, emotional, informational, and physical aspect shows an increased impact on their child's learning (Lowe \& Dotterer, 2018). Support and motivation from parents not only will aid students in handling academic and social pressure during their university period but may also influence their child's perception towards the educational institution and their behavior in class (Arshad \& Shahzadi, 2016). Therefore, the parents' trust and hope in their child will increase their self-efficacy, self-worth, and the student's tendency to exhibit positive behavior in their learning (Khajehpour, 2011). Parental concern towards learning problems, current performance, and engagement in academic tasks influences the student engagement in their child's math learning (Jelas et al., 2016; Lowe \& Dotterer, 2018; Mehdinezhad, 2011). Based on this study's findings, the responsibility to repay parents may also be among the reasons why there is a relationship between parental involvement with working on in-class problems and the amount of homework completed. Seeing that students are now adults and that most of them are supported by their parents, parental gratitude and empathy may contribute significantly to moderate student engagement in math learning.

\section{Conclusion}

Overall, this study suggests that adequate learning practice studies, i.e., seating location, attentive listening, note-taking, working on in-class problems, and the amount of homework completed, can increase student engagement in math learning. In terms of social factors, teaching practices show a significant relationship with attentive listening, note-taking, and working on in-class math problems. In comparison, parental involvement can influence their child's learning practices linked to solving math problems inside or outside of class. Even though many learning activities are shared with their peers, these only influence a student's attentive listening. Findings were evocative of social factors' role in the relationship between learning practices and student engagement in math learning. 


\subsection{Study Implications}

Through this study, the five dimensions of learning practices that can increase student engagement when learning math are identified. Students' acceptable learning practices demonstrate that the student factor is the most significant and can affect their engagement. As stated in the Self Determination Theory, a precise learning aim can move the student to perform a task (Deci \& Ryan, 1985, 2000). Other than that, learning aims can also motivate students to manage time effectively to complete their academic tasks (Valle et al., 2016).

The Flow Theory suggests a balance between students' perception of learning challenges and their teaching skills to improve the learning experience quality. The findings are concurrent with the concept of credit in the Flow Theory related to the lecturer's role in forming acceptable learning practices and student engagement. Therefore, the results obtained are found to add value to past studies. The findings from this study suggest the teaching that encompasses the readiness to help and the concern towards developing the student's learning in math. Among the learning practices that assist in math learning is an easily contactable lecturer and is fair in his or her evaluations. With these methods, an excellent lecturer-student relationship can be built by promoting student engagement (Lee, 2012; Muda et al., 2012; Vansteenkiste et al., 2012) and will be the catalyst the retaining and increasing of learning outcomes (Appleton et al., 2008).

Moreover, a lecturer who shows concern towards the student's learning is also seen as able to push student engagement and commitment towards learning math. Although peers influence only attentive listening, the data analysis results indicated that peers must learn math. It is found that some students require assistance from their friends with work related to learning math in university. Therefore, this study suggests more learning activities that involve group work to increase student engagement in math. This suggestion is highlighted as the excellent relationship between students can provide a more enjoyable learning experience and university life (Zhang et al., 2015). From a parental involvement side, the support in physical, informational, and encouragement is crucial. The study findings reveal that parental involvement positively impact towards mathematical problem solving and implementation of tasks.

This study contributes to the literature on the role acceptable learning practices play and the relationship with social factors such as student engagement indicators in learning math at a university level. Based on the student sampled in this study, the findings offer empirical support for the hypothesis that student perception towards social factors influences their learning practices and the hypothesis that learning practices influence student engagement when learning math. In conclusion, the knowledge obtained from this study contributes towards new input to the researchers in math and can be used as a basis for research expansion in the future.

\subsection{Limitations and Suggestion}

Several limitations restrict generalization found in this study. Firstly, this study focuses on social factors, learning practices, and student engagement in learning math. Secondly, the sample chosen was limited to degree students undertaking math courses offered at the study site. Therefore, this study's findings may not be suitable to be generalized for all courses or even other levels. Third, these study findings are based on the correlated data that excluded the researcher from inferencing the relationship between the variables. Therefore, a long-term longitudinal study would help provide more substantial validity for the current findings.

The engagement in classes and academic tasks and the engagement with the lecturers and peers are included as the student engagement concept that can impact academic achievement. Thus, future studies might need to explore the characteristics of 1) lecturer readiness and concern, 2) peers' positive influence through group learning activities, and 3) parental support, and if these can be applied to other academic circles or younger students.

\section{References}

[1]. Abd Razak Zakaria, \& Noraini Mohd Salleh. (2011). Konteks keluarga dan hubungannya dengan penglibatan ibu bapa dalam pendidikan anak-anak di sekolah menengah. Jurnal Pendidikan Malaysia, 36(1), 35-44.

[2]. Al-Alwan, A. F. (2014). Modeling the relations among parental involvement, school engagement, and academic performance of high school students. International Education Studies, 7(4), 47-56. https://doi.org/10.5539/ ies.v7n4p47

[3]. Allison, P. D. (2003). Missing Data Techniques for Structural Equation Modeling. Journal of Abnormal Psychology, 112(4), 545-557. https://doi.org/10.1037/ 0021-843X.112.4.545

[4]. Arshad, M., \& Shahzadi, E. (2016). Parents involvement at university level education: students perception in under developing country. European Scientific Journal, 12(22), 294-304. https://doi.org/10.19044/esj.2016. v12n22 p294

[5]. Attard, C. (2012). The influence of pedagogy on student engagement with math during the middle years of schooling. In A. L. White \& U. H. Cheah (Eds.), Transforming School Math in the 21 st Century (140- 
157).

[6]. Bembenutty, H., \& White, M. C. (2013). Academic performance and satisfaction with homework completion among college students. Learning and individual differences, 24, 83-88. https://doi.org/10.1016/j.lindif. 2012.10.013

[7]. Buijs, M., \& Admiraal, W. (2013). Homework assignments to enhance student engagement in secondary education. European Journal of Psychology of Education, 28(3), 767-779. https://doi.org/10.1007/ s10212012- 0139-0

[8]. Byrne, B. M. (2010). Structural equation modeling with AMOS: Basic concepts. applications, and programming (multivariate applications series). New York: Taylor \& Francis Group.

[9]. Carter, J. F., \& Van Matre, N. H. (1975). Note-taking versus note-having. Journal of Educational Psychology, 67(6), 900-904. https://doi.org/10.1037/00220663.67.6.900

[10]. Conner, T. (2016). Relationships: The key to student engagement. International Journal of Education and Learning, 5(1), 13-22. http://dx.doi.org/10.14257/ ijel.2016.5.1.02

[11]. Csikszentmihalyi, M. (1990). Flow: The psychology of optimal experience. New York: Harper and Row.

[12]. Csikszentmihalyi, M. (2014). Toward a psychology of optimal experience. In Flow and the foundations of positive psychology (pp. 209-226). Dordrecht: Springer. https://doi.org/10.1007/978-94-017-9088-8

[13]. Deci, E. L., \& Ryan, R. M. (1985). Intrinsic Motivation and Self-Determination in Human Behavior. New York: Springer. https://doi.org/10.2307/2070638

[14]. Deci, E. L., \& Ryan, R. M. (2000). The "what" and "why" of goal pursuits: Human needs and the selfdetermination of behavior. Psychological inquiry, 11(4), 227-268. https://doi.org/10.1207/S15327965 PLI1104

[15]. Deka, P. P. (2016). A study on parental involvement in higher level of education: Voices of parents and students in Pub-Kamrup College and Patidarrang College, Kamrup district. The Clarion-International Multidisciplinary Journal, 5(1), 57-64. https://doi.org/10.5958/2277937X.2016.00009.5

[16]. Durksen, T. L., Way, J., Bobis, J., Anderson, J., Skilling, K., \& Martin, A. J. (2017). Motivation and engagement in math: A qualitative framework for teacher-student interactions. Math Education Research Journal, 29(2), 163-181. https://doi.org/10.1007/s13394-017-0199-1

[17]. Engels, M. C., Colpin, H., Van Leeuwen, K., Bijttebier, P., Van Den Noortgate, W., Claes, S., Goossens, L., \& Verschueren, K. (2016). Behavioral engagement, peer status, and teacher-student relationships in adolescence: A Longitudinal Study on reciprocal influences. Journal of Youth and Adolescence, 45(6), 1192-1207. https://doi.org/10.1007/s10964-016-0414-5

[18]. Fan, H., Xu, J., Cai, Z., He, J., \& Fan, X. (2017). Homework and students' achievement in math and science: A 30-year meta-analysis, 1986-2015. Educational Research Review, 20, 35-54. https://doi.org/10.1016/j. edurev.2016.11.003

[19]. Fernández-Alonso, R., Suárez-Álvarez, J., \& Muñiz, J. (2015). Adolescents' homework performance in Math and Science: Personal factors and teaching practices. Journal of Educational Psychology, 107(4), 1075-1085. https://doi.org/10.1037/edu0000032

[20]. Fernandes, A. C., Huang, J., \& Rinaldo, V. (2011). Does where a student sits really matter? -The impact of seating locations on student classroom learning. International Journal of Applied Educational Studies, 10(1), 66-77.

[21]. Fisher, J. L., \& Harris, M. B. (1974). Note-taking and recall. The Journal of Educational Research, 67(7), 291-292. https://doi.org/110.1037/h0035640

[22]. Flunger, B., Trautwein, U., Nagengast, B., Lüdtke, O., Niggli, A., \& Schnyder, I. (2017). A personcentered approach to homework behavior: Students' characteristics predict their homework learning type. Contemporary Educational Psychology, 48, 1-15. https://doi.org/10.1016/j.cedpsych.2016.07. 002

[23]. Fredricks, J. A., Blumenfeld, P. C., \& Paris, A. H. (2004). School engagement: Potential of the concept, state of the evidence. Review of Educational Research, 74(1), 59-109. https://doi.org/10.3102/00346543074001059

[24]. Fredricks, J. A., Wang, M. T., Linn, J. S., Hofkens, T. L., Sung, H., Parr, A., \& Allerton, J. (2016). Using qualitative methods to develop a survey measure of math and science engagement. Learning and Instruction, 100(43), 5-15. https://doi.org/10.1016/j.learninstruc.2016.01.009

[25]. Furrer, C. J., Skinner, E. A., \& Pitzer, J. R. (2014). The influence of teacher and peer relationships on students' classroom engagement and everyday motivational resilience. National Society for the Study of Education, 113(1), 101-123.

[26]. Gerber, C., Mans-kemp, N., \& Schlechter, A. (2013). Investigating the moderating effect of student engagement on academic performance. Acta Academica, 45(4), 256-274.

[27]. Grolnick, W. S., \& Slowiaczek, M. L. (1994). Parents' involvement in children' s schooling: A multidimensional conceptualization and motivational model. Child Development, 65(1), 237-252. https://doi.org/10.2307/ 1131378

[28]. Gunuc, S. (2014). The relationships between student engagement and their academic achievement. 
International Journal on New Trends in Education and Their Implications, 5(4), 216-231.

[29]. Gunuc, S., \& Kuzu, A. (2015). Student engagement scale: development, reliability, and validity. Assessment \& Evaluation in Higher Education, 40(4), 587-610. https://doi.org/10.1080/02602938.2014.938019

[30]. Hair, J. F., Black, W. C., Babin, B. J., \& Anderson, R. E. (2010). Multivariate data analysis (7 $7^{\text {th }}$ ed.). Upper Saddle River, N.J.: Pearson Prentice Hall.

[31]. Harper, C. E., Sax, L. J., \& Wolf, D. S. S. (2012). The role of parents in college students' socio-political awareness, academic, and social development. Journal of Student Affairs Research and Practice, 49(2), 137-156. https://doi.org/10.1515/sharp-2012-6147

[32]. Heng, K. (2014a). The effects of faculty behaviors on the academic achievement of first-year Cambodian urban university students. Educational Research for Policy and Practice, 13(3), 233-250. https://doi.org/10.1007/ s10671-013-91 59-z

[33]. Heng, K. (2014b). The relationships between student engagement and the academic achievement of firstyear university students in Cambodia. The Asia-Pacific Education Researcher, 23(2), 179-189. https://doi.org/ 10.1007/ s40299-01300 95-8

[34]. Holland-Minkley, A. M., \& Lombardi, T. (2016). Improving engagement in introductory courses with homework resubmission. In Proceedings of the 47th ACM Technical Symposium on Computer Science Education. 534-539. http://dx.doi.org/10.1145/2839509.2844576

[35]. Holliman, W. B., \& Anderson, H. N. (1986). Proximity and student density as ecological variables in a college classroom. Teaching of Psychology, 200-203. http://doi.org/10.1207/s15328023top1304_7

[36]. Jelas, Z. M., Azman, N., Zulnaidi, H., \& Ahmad, N. A. (2016). Learning support and academic achievement among Malaysian adolescents: the mediating role of student engagement. Learning Environments Research, 19(2), 221-240. https://doi.org/10.1007/s10984-015-9202-5

[37]. Jover, J. M. N., \& Ramírez, J. A. M. (2018). Academic Performance, Class Attendance and Seating Location of University Students in Practical Lecture. Journal of Technology and Science Education, 8(4), 337-345. https://doi.org/10.3926/jotse.353

[38]. Kahu, E. R. (2013). Framing student engagement in higher education. Studies in higher education, 38(5), 758-773. https://doi.org/10.1080/03075079.2011.598505

[39]. Ketonen, E. E., Haarala-Muhonen, A., Hirsto, L., Hänninen, J. J., Wähälä, K., \& Lonka, K. (2016). Am I in the right place? Academic engagement and study success during the first years at university. Learning and Individual Differences, 51, 141-148. https://doi.org/10.1016/j.lindif.2016.08.017

[40]. Khajehpour, M. (2011). Relation between emotional intelligence, parental involvement, and academic performance of high school students. Procedia-Social and Behavioral Sciences, 15, 1081-1086.

[41]. Kessels, U., Heyder, A., Latsh, M., \& Hannover, B. (2014). How gender differences in academic engagement relate to students' gender identity. Educational Research, 56(2), 220-229. http://dx.doi.org/10.1080/ 00131881.2014.898916

[42]. Kiewra, K. A. (1989). A review of note-taking: The encoding-storage paradigm and beyond. Educational Psychology Review 1(2), 147-172. http://doi.org/10.1007/bf01326640

[43]. Kiewra, K. A., Dubois, N. F., Christian, D., McShane, A., Meyerhoffer, M., and Roskelley, D. (1991). Note-taking functions and techniques. Journal of Educational Psychology, 83(2), 240-245. http://doi.org/10.1037/0022-0663.83.2.240

[44]. Lam, S. F., Jimerson, S., Shin, H., Cefai, C., Veiga, F. H., Hatzichristou, C., Polychroni, F., Kikas, E., Wong, B.P., Stanculescu, E., \& Basnett, J. (2016). Cultural universality and specificity of student engagement in school: The results of an international study from 12 countries. British Journal of Educational Psychology, 86(1), 137-153. https://doi.org/10.1111/bjep.12079

[45]. Leach, L. (2016). Enhancing student engagement in one institution. Journal of Further and Higher Education, 40(1), 23-47. https://doi.org/10.1080/0309877X.2013.869565

[46]. Lee, W., \& Reeve, J. (2012). Teachers' estimates of their students' motivation and engagement: Being in synch with students. Educational Psychology, 32(6), 727-747. http://dx.doi.org/10.1080/01443410.2012.732385

[47]. Liu, F., Black, E., Algina, J., Cavanaugh, C., \& Dawson, K. (2010). The validation of one parental involvement measurement in virtual schooling. Journal of interactive online learning, 9(2), 105-132. www.ncolr.org/jiol

[48]. Lowe, K., \& Dotterer, A. M. (2018). Parental involvement during the college transition: a review and suggestion for its conceptual definition. Adolescent Research Review, 3(1), 29-42. https://doi.org/10.1007/s40894-017-0058-z

[49]. Lynch, A. D., Lerner, R. M., \& Leventhal, T. (2013). Adolescent academic achievement and school engagement: An examination of the role of school-wide peer culture. Journal of Youth and Adolescence, 42(1), 6-19. https://doi.org/10.1007/s10964-012-9833-0 
[50]. Maron, A. I. (2016). Priorities of teaching math in universities. International Electronic Journal of Math Education, 11(9), 3339-3350.

[51]. Marx, A., Fuhrer, U., \& Hartig, T. (2000). Effects of classroom seating arrangements on children's question asking. Learning Environments Research, 2, 249-263. https://doi.org/10.1023/1009901922191

[52]. Meeks, M. D., Knotts, T. L., James, K. D., Williams, F., Vassar, J. A., \& Wren, A. O. (2013). The impact of seating location and seating type on student performance. Education Sciences, 3(4), 375-386. https://doi.org/ 10.3390/educsci3040375

[53]. Mehdinezhad, V. (2011). First-year students' engagement at the university. International Online Journal of Educational Sciences, 3(1), 47-66.

[54]. Mehmood, N., Ahmed, K., Sultana, A., \& Irum, S. (2012). Relationship between homework and students' grades (a study of higher education sector in Pakistan). Interdisciplinary Journal of Contemporary Research in Business, 4(6), 700-713.

[55]. Mfaume, H., Bilinga, M., \& Mgaya, R. (2018). From Paper and Pencil to Mobile Phone Photo NoteTaking among Tanzanian University Students: Extent, Motives and Impact on Learning. International Journal of Education and Development using Information and Communication Technology, 14(2), 8398.

[56]. Min, Y., \& Chau, A. (2012). Social engagement in a diversifying campus: A phenomenological exploration. Higher Education Research \& Development, 31(2), 155-169. https://doi.org/10.1080/07294360.2010. 549462

[57]. Molloy, L. E., Gest, S. D., \& Rulison, K. L. (2011). Peer influences on academic motivation: Exploring multiple methods of assessing youths' most "Influential" peer relationships. The Journal of Early Adolescence, 31(1), 13-40. http://www.dx.doi.org/10.1177/0272431610384487

[58]. Montello, D. R. (1988). Classroom seating location and its effect on course achievement, participation, and attitudes. Journal of Environmental Psychology, 8(2), 149-157. https://doi.org/10.1016/s02724944(88) 80005-7

[59]. Muda, N., Samsudin, H. B., Majid, N., Ali, K. A. M., \& Ismail, W. R. (2012). Students perspective on lecturer characteristics for effective teaching. Procedia-Social and Behavioral Sciences, 59, 535-540.

[60]. Nguyen, T. D., Cannata, M., \& Miller, J. (2016). Understanding student behavioral engagement: Importance of student interaction with peers and teachers. The Journal of Educational Research, 111(2), 163-174. http://dx.doi.org/10.1080 00220671.2016.1220359

[61]. Núñez, J. C., Suárez, N., Cerezo, R., González-Pienda, J., Rosário, P., Mourão, R., \& Valle, A. (2015). Homework and academic achievement across Spanish Compulsory Education. Educational Psychology, 35(6), 726-746. https://doi.org/10.1080/01443410.2013.817537

[62]. Oliver, B., Tucker, B., Gupta, R., \& Yeo, S. (2008). eVALUate: An evaluation instrument for measuring students' perceptions of their engagement and learning outcomes. Assessment \& Evaluation in Higher Education, 33(6), 619-630. https://doi.org/10.1080/02602930701773034

[63]. Pintrich, P. R., \& De Groot, E. V. (1990). Motivational and self-regulated learning components of classroom academic performance. Journal of educational psychology, 82(1), 33-40. https://doi.org/10.1037/0022-663.82.1.33

[64]. Razali, S. N. A. M., Sufahani, S. F., \& Arbin, N. (2015). Pencapaian kursus matematik dan statistik di kalangan pelajar UTHM: Faktor mempengaruhi dan teknik pengajaran dan pembelajaran yang lebih diminati. Journal of Techno Social, 7(2).

[65]. Reeve, J., \& Tseng, C. M. (2011). Agency is a fourth aspect of students' engagement during learning activities. Contemporary Educational Psychology, 36(4), 257-267. https://doi.org/10.1016/j.cedpsych.2011.05.002

[66]. Reschly, A., \& Christenson, S. (2012). Jingle, jangle and conceptual haziness: Evolution and future directions of the engagement construct. In A. Christenson, A. Reschly, \& C. Wylie (Eds.), Handbook of research on student engagement, 3-19. Boston: Springer. https://doi.org/10.1007/978-1-4614-2018-7_1

[67]. Rosário, P., Carlos Núñez, J., Vallejo, G., Nunes, T., Cunha, J., Fuentes, S., \& Valle, A. (2018). Homework purposes, homework behaviors, and academic achievement. Examining the mediating role of students' perceived homework quality. Contemporary Educational Psychology, 53, 168-180. https://doi.org/10.1016/ j.cedpsych.2018.04.001

[68]. Salmela-Aro, K., Moeller, J., Schneider, B., Spicer, J., \& Lavonen, J. (2016). Integrating the light and dark sides of student engagement using person-oriented and situation-specific approaches. Learning and Instruction, 43, 61-70. https://doi.org/10.1016/j.learninstruc.2016.01.001

[69]. Sathappan, R., \& Sathappan, M. (2017). The effects of technology on peer relationships and interpersonal understanding: A case study at a teacher education institute in Malaysia. Journal of Social Science Research, 11(1), 2257-2267.

[70]. Shaari, A. S., Yusoff, N. M., Ghazali, I. M., Osman, R. H., \& Dzahir, N. F. M. (2014). The relationship between lecturers' teaching style and students' academic engagement. Procedia-Social and Behavioral 
Sciences, 118, 10-20. https://doi. org/10.1016/j.sbspro.2014.02. 002

[71]. Shernoff, D. J. (2013). Optimal Learning Environments to Promote Student Engagement. New York: Springer. https://doi.org/10.3102/0013189X14532521

[72]. Shernoff, D. J., Ruzek, E. A., Sannella, A. J., Schorr, R. Y., Sanchez-Wall, L., \& Bressler, D. M. (2017). Student engagement as a general classroom experience: Associations with student practices and educational outcomes in a university gateway course. Frontiers in Psychology, 994(8), 1-23. https://doi.org/10.3389/fpsyg. 2017.00994

[73]. Shernoff, D. J., Sannella, A. J., Schorr, R. Y., Sanchez-Wall, L., Ruzek, E. A., Sinha, S., \& Bressler, D. M. (2017). Separate worlds: The influence of seating location on student engagement, classroom experience, and performance in the large university lecture hall. Journal of Environmental Psychology, 49, 55-64. https://doi.org/10.1016/j.jenvp.2016.12.002

[74]. Shernoff, D. J., Tonks, S., \& Anderson, B. (2013). The impact of the learning environment on student engagement in high school classrooms. In D. J. Shernoff \& J. Bempechat (Eds.), Engaging youth in schools: Evidence-based models to guide future innovations, 113(1), 166-177. NSSE Yearbook by Teachers College Record.

[75]. Shernoff, D. J., Kelly, S., Tonks, S. M., Anderson, B., Cavanagh, R. F., Sinha, S., \& Abdi, B. (2016). Student engagement as a function of environmental complexity in high school classrooms. Learning and Instruction, 43, 52-60.

[76]. Skilling, K. (2014). Teacher Practices: How They Promote or Hinder Student Engagement in Math. In J. Anderson, M. Cavanagh \& A. Prescott (Eds.). Curriculum in focus: Research guided practice (Proceedings of the $37^{\text {th }}$ annual conference of the Math Education Research Group of Australasia). 589596. MERGA.

[77]. Stebleton, M. J., Soria, K. M., Huesman, R. L., \& Torres, V. (2014). Recent immigrant students at research universities: the relationship between campus climate and sense of belonging. Journal of College Student Development, 55(2), 196-202. https://doi.org/10.1353/csd.2014.0019

[78]. Svoboda, R. C., Rozek, C. S., Hyde, J. S., Harackiewicz, J. M., \& Destin, M. (2016). Understanding the relationship between parental education and STEM course taking through identity-based and expectancyvalue theories of motivation. AERA Open, 2(3), 1-13. https://doi.org/10.1177/2332858416664875

[79]. Uzezi, J. G., \& Deya, G. D. (2017). Relationship between peer group influence and students' academic achievement in Chemistry at secondary school level. American Journal of Educational Research, 5(4), 350-356. https://doi.org/10.12691/education-5-4-2

[80]. Valle, A., Regueiro, B., Núñez, J. C., Rodríguez, S., Piñeiro, I., \& Rosário, P. (2016). Academic goals, student homework engagement, and academic achievement in elementary school. Frontiers in Psychology, 7, 463. https://doi.org/10.3389/fpsyg.2016.00463

[81]. Vansteenkiste, M., Sierens, E., Goossens, L., Soenens, B., Dochy, F., Mouratidis, A., Aelterman, N., Haerens, L., \& Beyers, W. (2012). Identifying configurations of perceived teacher autonomy support and structure: Associations with self-regulated learning, motivation and problem behavior. Learning and Instruction, 22(6), 431-439. https://doi.org/10.1016/j.learninstruc.2012.04.002

[82]. Vollet, J. W., Kindermann, T. A., \& Skinner, E. A. (2017). In peer matters, teachers matter: Peer group influences on students? Engagement depends on teacher involvement. Journal of Educational Psychology, 109(5), 635-652. https://doi.org/10.1037/edu0000172

[83]. Wang, M. T., \& Degol, J. (2014). Staying engaged: Knowledge and research needs in student engagement. Child Development Perspectives, 8(3), 137-143. https://doi.org/10.1111/cdep. 12073

[84]. Wang, M. T., \& Eccles, J. S. (2012). Adolescent behavioral, emotional, and cognitive engagement trajectories in school and their differential relations to educational success. Journal of Research on Adolescence, 22(1), 31-39. https://doi.org/10.1111/j.1532-7795.2011.00753.x

[85]. Wang, M. T., Fredricks, J. A., Ye, F., Hofkens, T. L., \& Linn, J. S. (2016). The math and science engagement scales: Scale development, validation, and psychometric properties. Learning and Instruction, 43, 16-26. https://doi.org/10.1016/j.learninstruc.2016.01.008

[86]. Witkowski, P., \& Cornell, T. (2015). An Investigation into Student Engagement in Higher Education Classrooms. InSight: A Journal of Scholarly Teaching, 10, 56-67.

[87]. Zhang Z. (2016). Missing data imputation: focusing on single imputation. Annals of translational medicine, 4(1), 9. https://doi.org/10.3978/j.issn.23055839.2015.12.38

[88]. Zhang, Z., Hu, W., \& McNamara, O. (2015). Undergraduate student engagement at a Chinese university: A case study. Educational Assessment, Evaluation and Accountability, 27(2), 105-127. https://doi.org/10.1007/ s11092-015-9213-x 